\title{
A obra poética de Pablo Neruda: um estudo psicanalítico
}

\author{
Ismael Pereira de Siqueira \\ Rodrigo Otávio Fonseca \\ Sandra Maria da Silva Sales Oliveira ${ }^{1}$
}

\begin{abstract}
Resumo
Neste trabalho realizou-se uma leitura da obra poética de Pablo Neruda, conforme os pressupostos teóricos de Freud e Lacan. A preocupação inicial foi a de elaborar um esquema teórico que fornecesse subsídios ao estudo. Num segundo momento foi realizada uma leitura das principais obras que marcam os três períodos literários de Pablo Neruda, tentando-se interpretar psicanaliticamente a rede simbólica encontrada nessas obras. Com base nas análises realizadas, pôde-se observar que a poesia de Pablo Neruda parece possuir um papel de figura objetal, possibilitando ao autor religar-se às suas figuras parentais, nas quais projeta os seus desejos e frustrações.

Palavras-Chave: Psicanálise; Poesia; Pablo Neruda.
\end{abstract}

\section{The Pablo Neruda's poetic work: a psychoanalytical study}

\begin{abstract}
In this work a reading of Pablo Neruda's poetic work was done, according to a Freud's and Lacan's theoretical presuppositions. The first concern was to elaborate a theoretical schema to supply subsidies to this study. After, a reading of the most important works of Pablo Neruda's three literary periods was done, trying to interpret psychoanalytically the symbolic net of these works. Based on the these analysis, it was observed that Pablo Neruda's poetry seems to have an object figure role, causing the author to link again to his parents figures on whom he projects his desires and frustrations.
\end{abstract}

Keywords: Psychoanalysis; Poetry; Pablo Neruda.

\section{Introdução}

Martins (1999) relata que no Brasil ainda existe uma carência de estudos em Psicologia Social, argumentando que pela interação entre os conceitos de crítica literária e de ciências como a história, a psicologia e a sociologia podem constituir verdadeiros retratos do país e dos aspectos de sua sociabilidade. Nesse sentido, os estudos das relações entre psicanálise e literatura seriam de fundamental importância, pois, pela compreensão da subjetividade do escritor, bem como de sua manifestação na obra literária, pode-se chegar a uma compreensão do ambiente social no qual esse escritor desenvolveu as suas obras. Na América do Sul, um dos exemplos mais marcantes desta relação entre poesia, subjetividade e ambiente social pode ser encontrada na obra do poeta chileno Pablo Neruda.

Desde os seus primórdios, a psicanálise se utilizou da literatura para construir e dar suporte aos seus conceitos, e sem esse instrumento, talvez, a psicanálise não tivesse produzido o mesmo impacto sobre a sociedade moderna. Freud, ao longo de toda a sua elaboração teórica, utilizou-se das obras literárias, para tornar reais alguns dos conceitos de sua teoria, tais como: o Édipo Rei, de Sófocles; as tragédias de Shakespeare; os contos de fada; Gradiva de Jensen; dentre outros. Ao contrário das outras ciências que também encontram na obra literária o seu objeto de estudo, a psicanálise tenta interpretar e compreender a produção criativa do escritor em devaneio, demonstrando que o desejo vincula-se a uma diversidade de elementos, sempre tomados e reconstruídos na integração entre o escrito e quem o lê.

Neruda (1978), em Sobre una Poesía sin Pureza concorda com os pressupostos de Lacan (1998), quando relata

Assim seja a poesia que procuramos, gasta como por um ácido pelos deveres da mão, penetrada pelo suor e pela fumaça, cheirando a urina e a açucena salpicada

${ }^{1}$ Endereço para correspondência:

Av. Antonio Augusto Ribeiro, 155 - Jd. Sta. Elisa - Pouso Alegre-MG - 37550-000

E-mail: smsso@uol.com.br 
pelas diversas profissões que se exercem dentro e fora da lei. Uma poesia impura como um traje, como um corpo, com manchas de nutrição, e atitudes vergonhosas, com prega, observações, sonhos, vigília, profecias, declarações de amor e de ódio, bestas, arrepios, idílios, credos políticos, negações, dúvidas, afirmações, impostos. (p. 79)

Essa definição de poesia como algo impuro acaba por, novamente, remontar à subjetividade humana, sua constituição e tudo aquilo que fora recalcado e que, por sua vez, constitui a matéria-prima da criação poética, bem como, do devaneio que a origina. Assim, a poesia é, dentre as formas de criação literária, a que talvez melhor expresse a realidade interna do autor, levando o leitor ao estabelecimento de uma relação de identificação com esta realidade. Em outras palavras, a poesia leva o leitor a habitar o mundo fantasístico criado pelo poeta, porém, ao contrário do romance, na poesia o leitor choca-se diretamente com os afetos que dão suporte a esse mundo, visto que, nessa modalidade de criação literária, os personagens não possuem o papel de mediação simbólica que realizam num romance. $\mathrm{Na}$ poesia, essa mediação é feita pelo próprio autor e os devaneios que se manifestam em sua obra.

O sujeito moderno perdeu as certezas construídas pelas formações simbólicas das sociedades tradicionais, estando entregue ao desamparo. Assim, Kehl (2000) afirma que esse sujeito é, cada vez mais, obrigado a tornar-se um escritor de si mesmo, passando a buscar na fratria este elo de relação com a figura paterna anteriormente perdida. A autora defende que pela literatura, o sujeito encontrará uma das formas de desenvolver esta relação de fraternidade, dando um novo sentido para a sua vida, na medida em que passa a se identificar com o cenário, os personagens e, até mesmo, com o autor de determinada obra.

\section{Aspectos Fenomenológicos da Obra Literária}

Diferentemente de outras abordagens, a perspectiva fenomenológica focaliza-se quase que inteiramente na experiência subjetiva envolvendo as questões pessoais dos indivíduos sobre os eventos. Logo, a primeira condição fundamental para se observar fenomenologicamente uma obra literária é introduzirlhe uma significação e assegurar-lhe uma existência interna (Ramos, 1974).

Um problema teórico antigo é a relação que se estabelece entre linguagem e pensamento. A comunicação é, obviamente, a razão principal da fala. A linguagem está intimamente ligada ao pensamento. Ao mesmo tempo, esta capacidade de se "pensar o que está pensando" faz do homem um ser sensível. A dor ou prazer que ele sente são tão fortes não porque apenas os sente, porém, a força dessas sensações deve-se ao fato de o homem ter consciência do que está sentindo. Portanto, o homem será tanto mais homem quanto maior for o domínio da linguagem.

Segundo Ramos (1974), o pensamento do lingüista Saussure é perpassado pela afirmação de que nada que esteja além ou aquém da linguagem pode possuir existência no real, e a linguagem, em todas as suas formas de manifestação, é composta de estruturas denominadas Signos. Confirmando essa afirmação, pode-se tomar as palavras de Bosi (1997) p. 39: "A linguagem humana é pensamento-som, conforma a expressão feliz de Saussure. Mas nem o pensamento nem o som comunicam-se por si mesmos: aparecem, para o homem em sociedade, já reunidos em articulações que se chamam signos."

O signo lingüístico é composto por um significante, arbitrário e imotivado, em relação ao seu respectivo significado, e possui a função de servir-lhe de veículo. No signo poético, significante e significado acabam por fundir-se numa única realidade, tornandose inseparáveis (Ramos, 1974).

A obra literária não é um sistema fechado, ou seja, acabado e equilibradamente estruturado. Assim, Ramos (1974) relata que toda obra literária pode ser interpretada de diferentes maneiras, sem que isso comprometa a sua configuração original, portanto, a obra literária é um sistema aberto. Cada vez que o leitor toma contato com um texto literário, ele acaba por reinventá-lo, na medida em que o reinterpreta segundo as suas representações psíquicas.

No contínuo ato de recriação da obra literária, a intuição sensível ganha um papel fundamental, afinal, esta é a via que propiciará a percepção ou evidenciação das imagens poemáticas na consciência, porém, o papel da intuição sensível é muito mais amplo, sendo também a base da instalação de uma consciência reflexiva aberta à compreensão da obra literária, no leitor, o que se correlacionará diretamente com o sentido estético desenvolvido no leitor ao longo da leitura de determinado texto literário. A esse respeito, afirma Ramos (1974, p. 45): "todo mundo crê sentir ou suspeitar algo, ainda quando desconheça o idioma em que estão escritos os versos. Ouve sons e ritmos, e, transcendendo ao entendimento discursivo, se sente tocado pelo estado interior do poeta." Ao falar da imagem no poema, Bosi (1997) afirma que 
A experiência da imagem anterior à palavra, vem enraizar-se no corpo. A imagem é afim à sensação visual. O ser vivo tem, a partir do olho, as formas do sol, do mar e do céu. O perfil, a dimensão, a cor. A imagem é um modo de presença que tende a suprir o contato direto $e$ manter, juntas, a imagem do objeto e a existência em nós. $O$ ato de ver apanha não só a aparência da coisa, mas alguma relação entre nós e essa aparência: primeiro e fatal intervalo. (p. 13)

A imagem é uma consciência. A palavra imagem não poderá, pois, designar nada mais que uma relação da consciência com o objeto. A consciência imaginante põe seu objetivo como nada, pois toda consciência é consciência de algo. A consciência aparece para si mesma como criadora. Para o autor, é no plano da consciência da direção sem palavras que se dá o estágio em que nos esforçamos para explicitar ou exteriorizar com palavras a essência de um conteúdo objetivo, que vivemos precisamente como interiorizado possuindo um estado mais ou menos intuitivo (Sartre, 1998).

Bosi (1997) também escreve que a imagem pode ser obscurecida, encoberta, estando a sua duração menos vinculada à ação do tempo em relação à força e à qualidade dos afetos que secundaram no momento de sua fixação.

\section{Elementos para uma Abordagem Psicanalitica da Obra Literária}

Segundo Xavier (1978), o termo "poesia" é utilizado para designar a estrutura verbal também chamada poema, que se apresenta na forma de frases em linhas com extensão determinada, denominadas versos. As palavras que compõem cada verso devem estar subordinadas à regras prosódicas, organizadas sob a forma de ritmo. Para que um texto se caracterize como poético, deve levar ao estabelecimento de uma relação emotiva, sentimental ou estética entre a sua forma, seja poema lido ou escrito, e a sensibilidade do ouvinte ou leitor. Por último, o poema suscita uma relação de cunho subjetivo, caso que se diz: "esta poesia é poética"; "este poema possui poesia".

O mistério, o inusitado, o imprevisível convivem na poesia e também na psicanálise. Entre uma linha e outra, nos pedaços em que não se escreve nada, aí ele surge. $\mathrm{O}$ poeta e o inconsciente falam por enigmas. $\mathrm{O}$ sentimento poético que vive em todos nós não pode ser transposto para o papel ou para a voz sem a perda de substância. Algo se perde na transposição, pelo fato de toda poesia ser feita de palavras, com as idéias e afetos servindo-lhes de substrato (Ramos, 1974).
As pulsões de vida e morte fazem-se conhecer - no espaço da consciência - no modo da imagem, sendo preciso ir além do recalcamento para se obter uma expressão imediata, ou seja, uma suposta apreensão das pulsões em si, como relata Ricoeur (1965) apud Bosi (1997). Segundo a teoria psicanalítica, sabe-se que essas imagens podem ser acessadas somente por via indireta, como por exemplo, em suas manifestações oníricas. Assim, a imagem, vinculada aos processos de condensação e deslocamento, assume diversas fisionomias para atingir o seu objetivo de exibir-mascarar o objeto do desejo, manifestando-o pelos sonhos, lapsos, atos falhos e devaneios que constituem o passo inicial da criação poética. A ênfase que Freud (1976) coloca na infância, ao analisar uma obra de arte como a de Leonardo Da Vinci, por exemplo, deriva da suposição de que a obra de arte como devaneio é um substituto do brincar infantil. $\mathrm{O}$ psicanalista Jacques Lacan retoma o conceito freudiano de fantasia, além de se dedicar amplamente ao fenômeno lingüístico na estrutura e no campo psicanalítico.

Em seu artigo "Escritores Criativos e Devaneios”, Freud (1976) propõe que a atividade de criação literária é semelhante ao brincar infantil, na medida em que o escritor investe uma grande parcela de sua libido num mundo de fantasia que ele cria, tal qual a criança que brinca, levando esse mundo muito à sério, enquanto mantém uma separação nítida entre ele e a realidade. A irrealidade desse mundo é de suma importância para a construção de uma obra literária, afinal, muito daquilo que poderia não causar prazer se fosse real, pode fazê-lo no mundo da fantasia, tão insistente e inutilmente renunciado pelos adultos. Assim, pode-se perguntar: por que a obra de arte produz prazer, quando o relato direto das fantasias de uma pessoa nos causa indiferença ou repulsa? A "ars poetica" ou a técnica do escritor ou poeta é o que leva a superar essas barreiras; ou porque o escritor nos suborna com o prazer puramente formal ou estético que suaviza ou disfarça o caráter egocêntrico de seus devaneios; ou porque o escritor proporciona ao leitor um prazer semelhante ao seu: ao devanear o leitor deleita-se com as suas próprias fantasias e libera-se de suas tensões (Freud, 1976, p. 142).

Segundo Roudinesco e Plon (1998), Jacques Lacan sublinha desde muito cedo a fantasia como uma função defensiva, sendo então assimilada como uma maneira de impedir um episódio traumático. Além da diversidade das fantasias de cada sujeito, Lacan (1998) postula a existência de uma fantasia fundamental, 
materializada não só num remanejamento das defesas, mas como uma expressão última na lógica do desejo.

Násio (1998) resgata a questão da fantasia como reconhecimento da expressão do inconsciente, estruturado como uma linguagem. $\mathrm{O}$ autor propõe a fantasia como instância que comporta cenas, personagens, afetos, exprimindo sonhos e devaneios, expressando por um relato e um ato, como um roteiro detalhado minuciosamente como enigmático. Esse relato retrata uma cena imaginada com seus locais, suas cores, sua luz e seu som, discernindo no relato os personagens da cena em que desenrola a ação, intensa de tensão e tramas que se desenrolam em uma ação principal.

Em conformidade com o inconsciente estruturado como uma linguagem em que toda dinâmica da fantasia envolve o mecanismo dinâmico da transferência, Násio (1998), analisa a fantasia como uma matriz formal composta essencialmente de quatro elementos, quais sejam, um sujeito, um objeto, um significante e imagens. Esse significante, de acordo com Roudinesco e Plon (1998), seria um elemento significativo no discurso consciente e inconsciente que determina os atos e as palavras do sujeito.

A palavra não é tradução de um sentido mudo, porém, a criação de um sentido. A linguagem não veste idéias, ao contrário, encarna significações, estabelece a significação entre o eu e o mundo, sedimentando os significados que constituem uma cultura. A linguagem não é mais a seiva das significações, mas o próprio ato de significar, assim, o escritor, tal qual o homem falante, não pode governá-la voluntariamente (Ponty, 1980).

Lacan (1998), em seu relatório sobre a função do campo da palavra e da linguagem em psicanálise, relata, por exemplo, como o sonho tem uma estrutura de uma frase; a palavra como instrumento de distinção entre significante e significado, os símbolos, na medida em que símbolos querem dizer um pacto e em que, antes de qualquer coisa, são significantes do pacto em que se constituem como significado como objetos de uma troca simbólica. Entretanto, segundo Lacan (1998), o que está em jogo na psicanálise é o advento do sujeito, do pouco de realidade que o desejo habita, uma relação aos conflitos simbólicos, na medida em que esse simbólico fundamenta a eficácia de um tratamento que se apóia na fala. Roudinesco e Plon (1998) complementam que além de apoiar na fala, apóia ainda às fixações imaginárias, como designação de uma relação dual com a imagem do semelhante, ou seja, como lugar do eu por excelência. O simbólico e o imaginário, como meio de harmonização em nossa vida, são a experiência intersubjetiva em que o desejo se faz reconhecer. Segundo Lacan (1998) o problema é o das relações, no sujeito entre a linguagem e a fala.

Conclui-se, então, que a relação entre fantasia e obra literária é obvia - os devaneios se relacionam com as produções literárias e a escritura criativa. Um escritor modela seus devaneios, sua fantasia, numa forma que espera ser interessante para as outras pessoas. Pode-se estar certo de que os escritores não são diferentes de outras pessoas quanto à relação entre devaneios e desejos inconscientes. Seus devaneios oscilam entre uma ampla variedade de temas inconscientes, julgando pelos escritos que dele derivam, ou seja, de conflitos instintivos da infância. Não importa em que astúcia ou disfarce, com que satisfação se expresse, e, sobretudo, o que ele crê conscientemente ser propósito de sua obra, um escritor está sempre interessado em apresentar aos leitores suas relações diante de seus desejos inconscientes, isto é, seus devaneios.

\section{Análise Psicanalitica das Principais Obras de Pablo Neruda}

Nascido em 12 de julho de 1904, Ricardo

Neftali Reyes Basualto, mais conhecido pelo seu pseudônimo, Pablo Neruda, que adotaria como seu nome oficial em 1946, consagrou-se como um dos maiores poetas da língua castelhana de todos os tempos. A poesia desse autor, sua vida e seu pensamento têm uma estrutura circular de completa busca afirmativa e humanizadora, valorizando a busca da felicidade, da alegria e do gozo, bem como, o aspecto religioso da existência. Esse autor também possuía um intenso envolvimento com as questões políticas do Chile, ocupando os cargos de Cônsul na Birmânia e Senador, posteriormente filiando-se ao Partido Comunista e sofrendo diversas represálias por suas convicções políticas.

Em suas obras, Pablo Neruda traz a visão do mundo e da vida. Canta o amor, a esperança, a justiça. Fala do mar e da liberdade como bálsamos e respostas para corações escuros. Privilegia os contatos humanos, acreditando que não há poesia sem eles, e destaca ainda que a sociedade humana e seu destino são matéria sagrada e obrigação original para o poeta.

Um dos mitos mais correntes de Neruda é o do poeta instintivo, alheio a toda formação literária. Em certa medida, ele mesmo permitiu que se desenvolvesse essa crença ao expressar ostensivamente o seu desprezo pela erudição, pelo saber livresco.

São muitas as perspectivas que se pode escolher para descrever o desenvolvimento da poesia de Pablo Neruda; uma delas consistiria em examinar diferentes alternativas de seu diálogo com o mar, que nunca se interrompeu. $\mathrm{Na}$ poesia da adolescência e da primeira 
juventude (Crepusculário e Vinte Poemas de Amor), o mar o envolve todo, apaga as marcas individuais; é o elemento maternal em que a identidade aspira a se dissolver, a perder os seus limites (Edwards, 1999).

O livro que marca a sua maturidade é Residencia en la Tierra e a partir daí suas obras estão cheias de poemas de amizade, que se torna um dos temas principais, depois do motivo central do amor. Nessa época, sente-se rodeado pela lenta e inexorável destruição das coisas e dos seres. Cada morte individual é um reflexo dessa destruição geral e a coloca em primeiro plano, esbofeteando o poeta com a intuição desse processo corrosivo.

Edwards (1999) comenta que depois, nos anos de mais intenso compromisso político, o poeta procura reprimir esse panteísmo dissolvente. $O$ mar já não evocará símbolos maternais. Será uma força hostil, traiçoeira, que arrebata as vidas dos humildes pescadores. Sua última poesia é de recuperação e reconciliação. O poeta recolhe todos os fios do seu canto; sem se esquecer de um sequer, os seus velhos temas revivem, mas sem a agressividade de antes como em Canto General (1950).

Suas poesias trazem a perfeição com que se relaciona com a terra, tempo e homem; escreve para levar a felicidade universal; abrangem ruas, fábricas e todos os lugares das lutas humanas. Em sua obra Prólogos, o que mais chama a atenção é a maneira grandiosa com que se refere à literatura alheia e a análise crítica que faz dos trabalhos de outros autores, no entanto, trata-se de uma crítica justa capaz de converter cada escrito em poema.

Vinte Poemas de Amor e uma Canção Desesperada (19231924)

Vinte Poemas de Amor foi a obra que marcou a juventude do autor e, ainda que escrito às vezes em Santiago do Chile, essa obra tem como fundo a paisagem do Sul, especialmente, os bosques de Temuco, as grandes chuvas frias, os rios e o selvagem litoral sulino. Inspirado em uma pessoa que amou na época, cantou principalmente o amor e a sexualidade, mas fez referências à saudade, à solidão, aos sonhos e às tristezas como elementos figurativos de seu inconsciente, como desejos que persistem enquanto há vida ("Corpo de mulher, brancas colinas, coxas brancas, / pareces com o mundo na tua atitude de entrega. / Meu corpo de lavrador selvagem te escava / E faz saltar o filho do fundo da terra", Neruda, p. 42) ("Mas cai a hora da vingança, e te amo. / Corpo de pele, musgo de leite ávido e firme. / Ah os copos de peito! Ah os olhos de ausência! / Ah as rosas do púbis! A tua voz lenta e triste!", Neruda, p. 43).

Em Freud (1976), para cada indivíduo, os primeiros objetos sexuais são os da infância. Todos os objetos sexuais subseqüentes são edições posteriores daqueles. A paixão de Neruda por essa jovem está baseada em alguma figura, que na infância, inconscientemente, o excitava, tendo mais tarde vivido conscientemente essa fantasia com a mulher amada. Percebe-se como é poderoso e duradouro o efeito dos desejos da infância sobre a vida sexual adulta de uma pessoa ("Sinto viajarem teus olhos e é distante o outono: / boina cinzenta, voz de pássaro e coração de casa, / para onde emigram os meus mais profundos desejos / e caíam os meus beijos alegres como brasas" // "Céu (visto) de um navio. Campo (visto) dos montes. / Tua lembrança é de luz, de fumaça, de lago em calma! / Mais para lá dos teus olhos ardiam os crepúsculos. / Folhas secas de outono giravam na tua alma", Neruda, p. 44).

Nesse poema, o poeta participa, segundo Freud (1976), de uma crença animista quando volta ao pensamento infantil que toma parte importante na magia. Todos os objetos do meio de uma criança são inicialmente aceitos como tendo pensamentos, sentimentos e desejos, assim como ela. Toda a natureza está animada até que a experiência e seus pais lhe digam o contrário. São vestígios dessa crença que persistem em áreas da vida adulta do autor.

Salienta-se que o fato de ser escritor não o difere de outras pessoas na relação entre devaneios e desejos inconscientes. Pode-se dizer que o inconsciente é um lugar psíquico especial que deve ser entendido como um sistema de energia específica. É principalmente o lugar onde estão os conteúdos quase sempre reprimidos. Reprimidos porque os objetos se vão e deixam o sofrimento, porque os conflitos obrigam a abandonar os desejos. $\mathrm{O}$ simbolismo surge como resultado do conflito intrapsíquico e as tendências repressoras e o reprimido. Somente o que é reprimido necessita ser simbolizado. Pode-se relembrar um dos pensamentos fundamentais da psicanálise, expresso por Lacan (1998): "Somos lá onde pensamos e pensamos lá onde não somos." O pensamento ajuda a existência, mas é a existência que pesa no pensamento, pede auxílio quando sofre, enquanto tem dores, enquanto sente faltas. Não há duvidas de que essa obra possui um valor estético e poético que transcende em nossos dias. 
Residencia en la Tierra (1925-1935)

Como dito anteriormente, Residencia en la Tierra é a obra que marca a maturidade literária de Pablo Neruda e, segundo Edwards (1999), a principal característica dessa obra reside na marcante influência que o sentimento de destruição passa a exercer nos escritos do poeta. Destruição essa que não se restringe unicamente ao mundo exterior, porém, também atinge a esfera subjetiva do indivíduo, passando a ser enxergado como um depósito das máculas, das angústias, tristezas, enfim, dos males do mundo. Esse aspecto torna-se evidente em muitos versos de algumas das principais poesias de Residencia en la Tierra, compiladas em sua Antologia Poética (1999) ("Desnecessário, me olhando nos espelhos / com um gosto de semanas, de biógrafos, de papéis, / arranco de meu coração o capitão do inferno, / estabeleço cláusulas indefinida-mente tristes", Neruda, p. 53) ("Cadáveres adormecidos que com freqüência / dançam presos ao meu coração, / que cidades opacas percorremos(...)", Neruda, p. 57) ("Quanta sombra da que há em minha alma daria para te recuperar, e que ameaçadores me parecem os nomes dos meses, e a palavra inverno que som de tambor lúgubre tem", Neruda, p. 63).

Esse sujeito, cujo coração serve de lar para o "capitão do inferno", bem como, de palco para "cadáveres acorrentados" e que possui a alma imersa em sombras encarna a idéia do desamparo que segundo Freud (1912) apud Pereira (1999) nasce da constatação do indivíduo de que existe uma falta de garantia para as suas ações no mundo e, conseqüentemente, para o desenvolvimento de sua vida psíquica. A figura paterna, que seria a principal responsável por fornecer essas garantias, encontra-se simbolicamente morta, resultando em uma espécie de "asfixia" no ego do sujeito, que pode acabar por sufocá-lo totalmente, conduzindo o sujeito à neurose, ou até mesmo à psicose. Este carrasco que "asfixia" o ego do sujeito é o desejo, que conduz o sujeito à incompletude, mergulha-o no vazio da existência, colocando-o frente a frente com as suas frustrações, ou seja, com os objetos perdidos, que segundo Freud (1923) apud Gama (2001) podem ser introjetados pelo ego, levando o sujeito à melancolia. Esse sentimento passa a servir como uma forma de tentar fazer com que o sujeito abandone definitivamente o objeto de seu desejo, acabando por reestruturar o seu ego ("Sou eu empreendendo uma viagem funerária / entre as tuas cicatrizes amarelas: / sou eu com meus lamentos sem origem, / sem alimentos, insone, sozinho, / entrando escurecidos corredores, / chegando à tua matéria misteriosa", Neruda, p. 76).
O sujeito, portador da melancolia, asfixiado pelos males do mundo, em Residencia en la Tierra é evocado pela figura do cavaleiro, sempre vagando sem rumo pela existência e tendo a alma marcada pelos males do mundo, porém, é o cavalo que permitirá ao cavaleiro suportar esses males e impedir a sua própria destruição. ("Atravesso com ele sobre as igrejas, / galopo os quartéis desertos de soldados I e um exército impuro me persegue", Neruda, p. 55).

Cavalo e cavaleiro assumem aqui, novamente, o papel do desejo, porém, desta vez acabam por conduzir o sujeito à possibilidade da completude, a um novo mundo, onde, ele não mais se cansará de ser homem, contrariando a idéia de sujeito mostrada em Walking Around (Antologia Poética, p. 68). Esse novo mundo é expresso pelas idéias de céu e, sobretudo, de sonho, no qual o sujeito, usando sua atividade fantasística, terá a oportunidade de se realizar, de alcançar a tão sonhada completude, num outro mundo, moldado de acordo com a lógica de seus desejos ("Há um país extenso no céu,/ com os supersticiosos tapetes do arco-íris / e com vegetações vesperais: / para ali me dirijo, não sem certa fadiga, / pisando uma terra removida de sepulcros um tanto frescos, / eu sonho entre essas plantas de legume confuso", Neruda, p. 54) ("Eu ouço o sonho de velhos companheiros e mulheres amadas, / sonhos cujas batidas me quebrantam: / seu material de alfombra piso em silêncio, sua luz de papoula, mordo em delírio", Neruda, p. 57).

Um último aspecto, que não pode deixar de ser mencionado, diz respeito à idéia de morte, que carrega em si todos os aspectos até aqui descritos, afinal, o sujeito incompleto que vaga pelo mundo, sofrendo diretamente a ação do mesmo sobre os seus desejos acaba por deslocar as suas pulsões para a possibilidade de uma realização num outro plano de existência, que como falamos há pouco, apresenta-se nos símbolos do sonho e do céu. Assim, Residencia en la Tierra fornece um retrato bastante nítido da relação de medo e angústia estabelecida entre o sujeito e o choque com a possibilidade de sua própria finitude, que seria a gênese da sua sensação de vazio e fator que motiva a sua busca pela completude, tornando-o vulnerável a todo tipo de sofrimento que se encontra intimamente ligado com esta idéia.

\section{Canto Geral (1950)}

Ano de mil novecentos e cinqüenta. Período importante para Pablo Neruda, não só por publicar o livro: Canto Geral, como também por receber o Prêmio Internacional da Paz. Esse prêmio vem coroar uma fase 
menos intempestiva do poeta em suas poesias. Segundo Edwards (1999), Neruda nesse livro já abandona uma certa rebeldia em suas poesias, explorando a terra com suas raízes sem deixar de reconciliar com uma espécie de metamorfose com o simbolismo do oceano.

É com base nesse interjogo que a palavra de Neruda expressa seu ato. Um ato, conceitualmente psicanalítico, justamente por não ser esse ato, um ato qualquer. Esse ato, expresso pela palavra, mostra um Neruda necessitado de expressar suas pulsões, expressar seus desejos, desabitando-os do seu controle pela manifestação da linguagem. $\mathrm{Na}$ expressão psicanalítica, pode-se analisar quais as representações que Neruda estabelece como vínculo entre esse ato e seu próprio eu poético expresso em símbolos como a terra, as raízes, o oceano, o retorno às origens chilenas.

Analisando pela ótica da psicanálise, a linguagem de Neruda em $O$ Canto Geral impressiona por sua necessidade em estabelecer uma ligação lingüística entre conteúdos preenchidos pela sua paixão pelo mar ("Na ponta do trovão andei, / recolhendo sol no rosto, / e do oceano na boca", Neruda apud Edwards, 1999) e uma nova fase que representa inauguração de um novo sentido mais enraizado. Podemos analisar essa situação como um prenúncio da perda de um objeto projetado por Neruda para estabelecer uma ligação simbólica entre suas poesias e os acontecimentos em sua vida. Essa relação de objeto se instaura pela necessidade da repetição metafórica dos termos. Segundo Lacan (1998), a perda de um objeto é condição necessária para que surja um sujeito, para que haja uma distinção entre o que foi representado e o que realmente existe, como a terra e o mar para o poeta Neruda. Para ilustrar esses conceitos, no seu poema "Amor América" declama: "O homem terra foi, vasilha, pálpebra / de barro trêmulo, forma de argila, / foi cântaro caraíba (...)" (Neruda, p. 104).

Essa metamorfose humana criada por Neruda dá a impressão da passagem para o ato. Revela que o mesmo ato assume uma conotação simbólica, como se toda atividade pulsional do poeta presentifique-o como uma nova possibilidade de marcar sua fala. Fala essa que expressa o ato em um terreno de articulação entre a pulsão e a linguagem.

Para a psicanálise, quando tratamos da palavra devemos sempre inseri-la no campo da linguagem, revelando por meio de significantes, que segundo Roudinesco (1998) representam um elemento significativo do discurso consciente ou inconsciente que determina os atos, as palavras e o destino do sujeito, tanto a palavra dita como a não dita. No trecho do poema: "Alturas de Macchu Picchu", pode-se observar em Neruda uma necessidade de ascensão do seu sujeito a partir do desejo que nele habita por mudanças. Esse aspecto é retratado na cadeia simbólica que Neruda estabelece entre o mar e a terra ("O homem amassa a pétala de luz que recolhe / nos mananciais marinhos / e verruma o metal palpitante em suas mãos", Neruda, p. 109).

$\mathrm{O}$ ato de o homem amassar a pétala revela um instante de encontro, de recolhimento e transformação do que existe de palpável nas mãos do homem (a terra como representante da pétala, o metal em suas mãos), e que foram recolhidos nos mananciais do mar. Esse discurso Nerudiano se trata não só de um encontro com suas tradições poéticas, como também um encontro do poeta com seus significantes.

Segundo Fages (1975), a linguagem como ordem simbólica constitui o sujeito, o transcreve por uma trama de significantes, desde seu nascimento. Diante disso pode-se perceber no poema "Quero voltar ao sul", de Canto Geral do Chile uma premente necessidade de Neruda ao retorno à terra ("Doente em Vera Cruz, me lembro um dia / do sul, minha terra, um dia de prata / como um rápido peixe na água do céu"/ Neruda, p. 134). Esse aspecto contrasta com um pedido aos velhos símbolos oceânicos para interceder pela volta à antiga terra: "Oceano, traze-me / um dia do sul, um dia agarrado nas tuas ondas, / um dia de árvore molhada, traze um vento / azul polar para a minha bandeira fria" (Neruda, p. 135).

Lembrando novamente Fages (1975), a pulsão, que invade Neruda nesse momento serve como um empuxo que o envolve, traduzindo uma falta, um complemento maternal; implícito ao discurso como um pedido de demanda de resposta, pois não há, segundo a psicanálise, um discurso sem um pedido de resposta.

Existem em Canto Geral dois poemas de Neruda que retratam a terra não como um grande Outro (lugar onde se desloca o discurso), mas como uma metáfora da terra, como conquistada e explorada; na qual o colonialismo se apresenta, empossando os bens que a natureza tanto ofereceu ao poeta como fonte de inspiração. No poema "Os Conquistadores", Neruda transporta a significação das palavras a uma outra ordem de significantes que subentendem a terra como vítima dos conquistadores: "Arranham-se a terra, despenduram / jóias feitas com amor e espuma(...) / (...)até a ultima / jóia os abutres dividiram: / turquesas rituais salpicadas / pela carnificina, a veste / laminada de $\operatorname{prata}(. .)$.$" (Neruda, p. 117). Do mesmo poema, no$ trecho "Ercilla", Neruda relata a invasão do homem buscando dominar a natureza: “(...) territórios de raízes / se encontram com o homem que chegou da Espanha. / 
Invadem sua armadura com gigantesco líquen" (Neruda, p. 119).

No poema: "Os Libertadores", Neruda narra a saga daquele que vive da terra e que colhe dela seus frutos ("Acostumou os pés nas cascatas. / Educou a cabeça nos espinhos", Neruda, p. 121). A terra, sempre presente nesses poemas, retrata a vida imaginária de Neruda e também a maneira como representa para si mesmo sua história e a história de suas origens, característico do conceito de fantasia descrito por Roudinesco (1998). Podemos observar nessa mesma fase de suas poesias, didaticamente exposta, um acesso à linguagem que permite à mesma formar uma rede de significantes oferecidos no meio social e pela cultura, confirmando a idéia de que o inconsciente é estruturado como uma linguagem e que a mesma insere o sujeito no campo da cultura, no campo das cadeias simbólicas em que nossa fala nos expressa. As conquistas, os bens, os interesses, todos esses aspectos presentes nessa fase da produção poética de Neruda, produzida metaforicamente como um sintoma, uma produção de um nonsense, para que sua atividade imaginativa possa expressar de forma velada (ou inconsciente) o desejo do poeta de uma transformação gradual, pautada no resgate às cenas primeiras de sua infância. Esse desejo marcado por uma demanda de resgate em seus poemas se desdobra no discurso e no campo da linguagem como uma espécie de enunciação, um ato daquele que comunica (Fages, 1975).

Um dos poemas em $O$ Canto Geral que ilustra essa análise ao retorno às origens simbólicas de Neruda seria o poema "O Grande Oceano". Nele Neruda se atém novamente ao tema mar ("Toda a tua força volta a ser origem (...)", Neruda, p. 146).

Esse trecho do poema de Neruda e todo seu desenrolar poético posterior lembra Fages (1975), quando diz que o inconsciente é como um capítulo da história do sujeito, marcado por um branco, por uma linguagem, por um desejo primordial. $\mathrm{O}$ oceano nesse poema, além de promover uma condensação de seus conteúdos, expressa também um desejo de exaltação às coisas primeiras que marcaram a construção poética do autor ("Se dos teus dons e de tuas destruições, Oceano, minhas mãos / pudesse destinar uma medida, uma fruta, um fermento, / escolheria o teu repouso distante, as linhas do teu aço, / a tua extensão vigiada pela noite (...)", Neruda, p. 144).

O oceano pode ser correlacionado em termos psicanalíticos como elemento que compartilha com o poeta uma relação de objeto. Segundo Roudinesco (1998) essa relação de objeto designa as modalidades fantasísticas da relação do sujeito com seu mundo externo, tal como se apresentam nas escolhas do objeto (nesse caso em particular, o oceano) que esse sujeito efetua. Além dessa relação de objeto, podemos encontrar nesses poemas de Neruda um mecanismo psíquico denominado projeção, quando o sujeito projeta em um outro sujeito, ou em um objeto, desejos que provêm dele, mas cuja origem ele desconhece, atribuindo-lhe uma alteridade que lhe é externa (Roudinesco, 1998).

Portanto, tanto o oceano como a terra são movimentos que representam toda uma construção subjetiva de Neruda expressando seus conteúdos alusivos ao inconsciente de forma a expressar sua intensa ligação com os fenômenos naturais. Fenômenos esses que, anteriormente a essa fase, tinham uma ferocidade marcante e hostil, mas que agora e posteriormente em outras obras, como em Cem Sonetos de Amor (1959) e Memorial de Isla Negra (1964), têm o diálogo com o mar e com seus antigos símbolos poéticos com uma conotação mais compartilhada. Ao mesmo tempo, depois de viajar sem descanso pela terra, o poeta encontrou um lugar definitivo para se instalar com sua mulher, numa cidade oceânica. Nesse lugar, mais que um ponto geográfico determinado, está um espaço poético situado (Edwards, 1999).

Por isso pode-se pensar que seus poemas em Canto Geral (Canto General) caracterizem um prenúncio de repouso poético para o autor, um repouso sublimado pela volta; como a psicanálise sempre preconizou como o determinismo psíquico dos nossos conteúdos, como se fosse realmente impossível nos livrarmos de toda nossa construção subjetiva; como se na mente, assim como na natureza física que nos cerca, nada acontecesse por acaso ou de modo fortuito, não existindo, portanto, uma descontinuidade na nossa vida mental (Brenner, 1987).

\section{Considerações Finais}

Ao escrever, o homem se inscreve na matéria, imortalizando o seu pensar e o seu sentir. Escrever é, nesse sentido, um ato de imortalidade, dado que o homem é hoje o que foi ontem, e será amanhã o que é hoje. Ao escrever o seu hoje, que amanhã será passado, ele continuará presente. Por esse motivo, o domínio da escrita torna-se importante não somente quanto ao aspecto social ou profissional, mas principalmente quanto ao aspecto existencial.

Com base nos estudos realizados, pode-se observar que a poesia de Pablo Neruda, considerada em seus três períodos literários, parece possuir um papel de figura objetal, possibilitando ao autor religar-se às suas figuras parentais, nas quais projeta os seus desejos e 
frustrações, porém, esse aspecto mereceria ser posteriormente analisado num estudo mais específico.

\section{Referências}

Bosi, Alfredo. (1997). O ser e o tempo da poesia. São Paulo: Cultrix.

Brenner, Charles. (1987). Noções básicas de psicanálise. São Paulo: Imago.

Edwards, Jorge. (1999). Alguma coisa sobre Pablo Neruda e a sua poesia. In: Neruda, Pablo (1999). Antologia poética. Rio de Janeiro: J. Olímpio.

Fages, Jean-Batiste. (1975). Para compreender Lacan. Rio de Janeiro: Ed. Rio.

Freud, Sigmund. (1976a). Escritores criativos e devaneios. Edição Standard das Obras Completas de Sigmund Freud. v. IX. Rio de Janeiro: Imago.

Freud, Sigmund. (1976b). Leonardo da Vinci e uma lembrança de sua infância. Edição Standard das obras completas de Sigmund Freud. v. XI. Rio de Janeiro: Imago.

Gama, Carlos Alberto Pegolo da. (2001). Agorafobia: Um Estudo Psicanalítico. As Relações Entre o Espaço e a Subjetividade Humana. São Paulo. Depositário: Biblioteca Nadir Gouvêa Kfouri - PUCSP.

Kehl, Maria Rita. (2000). A constituição literária do sujeito moderno. Palestra proferida nos Estados Gerias de Psicanálise. São Paulo.

Lacan, Jacques. (1998). Escritos. Rio de Janeiro: Jorge Zahar.
Martins, G. F. (1999). As pulsões da palavra. Cult-Revista Brasileira de Literatura. Ano III. Novembro. São Paulo: Lemos.

Násio, Juan David. (1998). Cinco lições sobre Jacques Lacan. Rio de Janeiro: Jorge Zahar.

Neruda, Pablo. (1979). 20 Poemas de amor e uma canção desesperada. Rio de Janeiro: J. Olímpio.

Neruda, Pablo. (1981). Canto geral. São Paulo: Difel

Neruda, Pablo. (1999). Antologia poética. Rio de Janeiro: J. Olímpio.

Neruda, Pablo. (2002). Prólogos. Rio de Janeiro: Bertrand Brasil.

Pereira, Mário Eduardo da Costa. (1999). Pânico e desamparo - um estudo psicanalítico. São Paulo: Escuta.

Ponty, Merleau. (1980). Os pensadores. São Paulo: Abril Cultural.

Ramos, M. L. (1974). Fenomenologia da obra literária. Rio de Janeiro: Forense Universitária.

Roudinesco, Elizabeth \& Plon, Michel. (1998). Dicionário de psicanálise. Rio de Janeiro: Jorge Zahar.

Sartre, Jean Paul. (1978). Os pensadores. São Paulo: Abril Cultural.

Xavier, Raul. (1978). Vocabulário de poesia. Rio de Janeiro: Imago.

Recebido em 03/09/2002

Revisado em 29/11/2002

Aceito em 10/12/2002

Sobre os autores:

Ismael Pereira de Siqueira é aluno do curso de Psicologia e voluntário de iniciação científica da UNIVÁS (Universidade do Vale do Sapucaí, Minas Gerais).

Rodrigo Otávio Fonseca é aluno do curso de Psicologia e voluntário de iniciação científica da UNIVÁS (Universidade do Vale do Sapucaí, Minas Gerais).

Sandra Maria da Silva Sales Oliveira. Psicóloga, pedagoga, mestre em psicologia, docente da UNIVÁS (Universidade do Vale do Sapucaí, Minas Gerais). 
